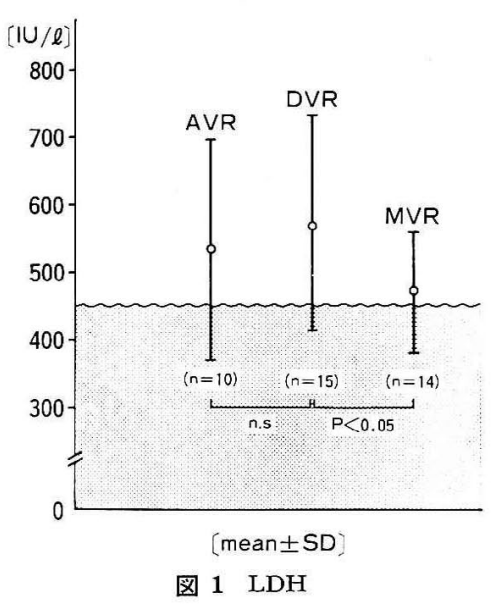

づく溶血による臨床的貧血は認められなかった。われわ れが昭和 54 年 6 月以降行った，手術死亡例を除いた， 202 例について, 移植弁の種類と血栓塞程症の 発生頻度 について対比すると，B-S 弁では $2.45 \% / 100 \mathrm{pt}-\mathrm{yr}$, 生体弁では $1.31 \% / 100 \mathrm{pt}-\mathrm{yr}$ であったが SJM 弁施行 144 例中血栓塞栓症例 2 例, $0.55 \% / 100 \mathrm{pt}-\mathrm{yr}$ と比較
的低值を示し，また二升置換症例には血栓塞栓症の発生 もなく良好な抗血柽性を示した。

\section{考察}

SJM 弁は, bileaflets, low profile といら新しい特徴を 有乙，1977 年より臨床的応用が開始され，その評価が 報告されてきた1,4-6). 今回われわれは二并置換術症例に ついて検討を加えた，人工弁を 1 ) 血行力学的機能,

2 ）安全性および耐久性，3）抗血程性，4）機械的溶 血，5）心内膜炎の観点より評価する とすれば，今 回 の二弁置換症例に関しても各項目とも良好な結果を得， 現時点では多弁置換症例においてもほぼ満足すべき人工 弁の一つであると考えている。

文 献 1) Nicoloff, D.M. et al. : JTCS $82: 674,1981$. 2) 古謝景春泀か：人工蔵器 $13: 311 ， 1984$. 3) 国吉幸男 か: 第13回胸部外科九州地方会, 1984. 4) Burckhardt, M.D. et al. : JTCS $88: 432,1984$. 5) Emery, R.W. et al. : Circulation $60: 48,1979 . \quad 6)$ Lillehei, C.W. : Cardiovasc. Med. 1 : 309, 1982.7 7) Bodnar, E.H. et al. : Br. Heart J. 42 : 541, 1979.

\title{
127 大動脈弁人工弁自身のもつ狭窄の流体力学的評価
}

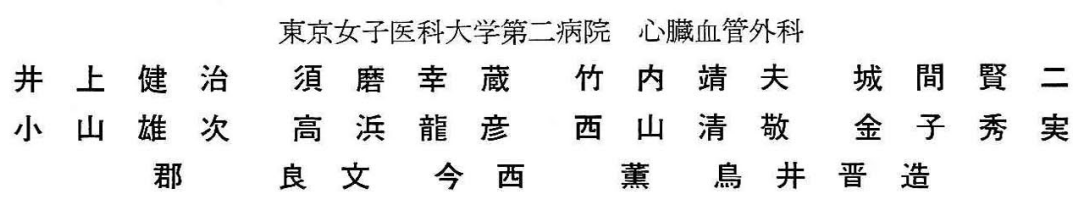

成人の大動脈弁人工弁置換術 (AVR) に括いて，一般 に機械弁であれば $21 \mathrm{~mm}$ 以上が縫着できればそれでよ いとされている.

そこで教室で St-Jude Medical (SJM) 升の $21 \mathrm{~mm}$ 以 上を用いて AVR を施行した症例につき，この人工弁の もつ狭窄の程度を, 圧力損失係数から流体力学的評価を おこなった.

\section{対象ならびに方法}

成人の AVR において SJM 弁で $21 \mathrm{~mm}, 23 \mathrm{~mm}$ を 使用したおのおの 5 例，4例を対象とした。 $21 \mathrm{~mm}$ を 使用した群の平均の年齢は $50.8 \pm 12.5$ 歳 (32〜67 歳), 平均体重 $45 \pm 8.8 \mathrm{~kg}(30 \sim 51.5 \mathrm{~kg})$ 平均体表面積 $1.37 \pm$
$0.16 \mathrm{~m}^{2}\left(1.13 \sim 1.53 \mathrm{~m}^{2}\right)$ であった. 一方 $23 \mathrm{~mm}$ を使用 した群の平均年齢 $53.8+13.1$ 歳（42６7 歳），平均体重 $55.5 \pm 4.2 \mathrm{~kg}(52.0 \sim 60.5 \mathrm{~kg})$, 平均体表面積 $1.57 \pm$ $0.02 \mathrm{~m}^{2}\left(1.55 \sim 1.6 \mathrm{~m}^{2}\right)$ であった。

手術室で心内操作終了後，胸骨を閉じる直前に左室お よび上行大動脈の圧を圧トランスデューサーで，大動脈 起始部の血流量を電磁血流計で計測し，それらを同時に ポリグラフに記録した。 大動脈血流波形は高域周波数を 25 または $30 \mathrm{~Hz}$ で遮断して計測し，その平均值（心拍 出量) は時定数 3 秒で計測した。 カフ式大動脈プローブ 内径を大動脈径とし，大動脈 ピーク流量 $(l / \mathrm{min})$ から ピーク流速 $(\mathrm{cm} / \mathrm{s})$ を求めた.

左室大動脈間のピーク圧差 $\Delta p(\mathrm{mmHg}) を ，$ 水銀の 
表 1 圧力損失保数 $(\lambda)$ と断面積比狭窄度 $\left(A_{1}-A_{0}\right) / A_{1}$ との関係

\begin{tabular}{cc}
\hline$\lambda$ & $\left(A_{1}-A_{0}\right) / A_{1}(\%)$ \\
\hline 226 & 90 \\
47.8 & 80 \\
17.5 & 70 \\
7.80 & 60 \\
3.75 & 50 \\
1.80 & 40 \\
0.797 & 30 \\
0.290 & 20 \\
0.060 & 10 \\
& 0 \\
\hline
\end{tabular}
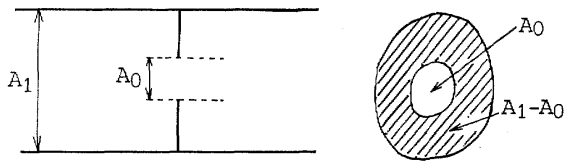

図 1 断面積比 (機能的) 狭窄度 $\left(A_{1}-A_{0}\right) A_{1}$

密度を $13.6 \mathrm{~g} / \mathrm{cm}^{3}$ として C.G.S. 系に変換し, 次式より 圧力損失係数 $(\lambda)$ を求めた。

$$
\lambda=\Delta p /(1 / 2) \rho U^{2}
$$

ただし， $\rho$ : 血液密度 $\left(1.05 \mathrm{~g} / \mathrm{cm}^{3}\right) ， U$ : 大動脈最大 流速 $(\mathrm{cm} / \mathrm{s}), \Delta p$ : 左室大動脈収縮期压差 $\left(\mathrm{g} / \mathrm{cm} \cdot \mathrm{s}^{2}\right)$ である。

さらに表 $10 よ う に ，$ 王力損失係数 $(\lambda)$ と断面積比狭 窄度 $(\%)$ との関係が実験的に検討された フィスに人工弁自身のもつ狭窄の程度を断面積比狭窄度 （図1）で示した.

\section{結果および考案}

SJM 弁 $21 \mathrm{~mm}, 23 \mathrm{~mm}$ を縫着した各症例の大動脈 径，左室大動脈間圧差，大動脈ピーク流量，大動脈最大 流速，圧力損失係数扣よび断面積比狭窄度は表 2 のごと くである.

一般に狭窄の程度を表すのは圧差でいらのが通常であ
るが，これだけでは不十分な場合がある。なぜなら圧力 損失は狭窄の強さのみでなく，流速によっても変わるか らである。

たとえばここでの症例で示せば，SJM 弁の $21 \mathrm{~mm}$ を 縫着した群では左室大動脈間収縮期圧差は平均 16.0 土 $6.5 \mathrm{mmHg}(5 \sim 20 \mathrm{mmHg})$ であり, 圧差だけからいえ ば問題となるものではなかった。

また前述の (1) 式より王力損失係数を求め, さらにこ れと断面積比狭窄度 $(\%)$ との関係が既知のオリフィスに 狭窄の程度を換算した ${ }^{1)}$. その結果，平均で $72.0 \pm 8.9$ \%と通常の心拍出量下では左室の後負荷として許容で きる範囲であった：しかし $75 \%$ 以上を呈した症例が 2 例あった，この原因として次のことが考光られた。

(1)式はすなわち

$$
\lambda=\frac{\Delta p \times r^{4}}{\left(C_{0}\right)^{2}} \times 90.1
$$

に変形して，通常臨床で用いる単位系 $(\mathrm{mmHg}, l / \mathrm{min})$ に変換できる，ここで 90.1 はその係数である.

$\Delta p$ 恃左室大動脈間圧差 $(\mathrm{mmHg}), r=$ 大動脈の半 径 すなわらプローブ内径の半径 $(\mathrm{cm}), C_{0}$ は大動脈ピーク 流量 $(l / \mathrm{min})$ である.

この式より明らかに圧力損失係数 $(\lambda)$ は，大動脈の 半径の 4 乗に比例するから, 大動脈狭窄症のよらに大動 脈弁上で急激に内腔が拡大するものすなわち poststenotic dilatation のあるものはこの圧力損失係数が当然大き くなってくる.

また（1）式より大動脈最大血流速度が遅くなればなる ほど，抵抗係数は大きくなる．断面積比狭窄度が $75 \%$ 以 上を示した症例の流速は $33.2 \sim 34.0 \mathrm{~cm} / \mathrm{s}$ であり，通常 の流速の約 $1 / 3$ であった。

これらの 2 症例は臨界狭窄が 75〜85\%といわれてい るので注意深い経過観察が必要と考克られる。な和 SJM 弁で $21 \mathrm{~mm}$ が縫着できた症例のらち2人ではあるが, treadmill test で Bruce 9 分以上の負荷が可能であり, 臨床上問題がなかった。

\begin{tabular}{|c|c|c|c|c|c|c|c|c|c|c|c|c|}
\hline \multirow{2}{*}{ SJM 弁 } & & \multicolumn{6}{|c|}{$21 \mathrm{~mm}$} & \multicolumn{5}{|c|}{$23 \mathrm{~mm}$} \\
\hline & & & & & & & 平 均 & & & & & 平 均 \\
\hline 大動脈径（プローブ径） & $(\mathrm{mm})$ & 30 & 32 & 32 & 30 & 26 & $30 \pm 2.4$ & 34 & 30 & 26 & 32 & $30.5 \pm 3.4$ \\
\hline 左室大動脈間圧差 & $(\mathrm{mmHg})$ & 20 & 20 & 5 & 15 & 20 & $16 \pm 6.5$ & 20 & 5 & 20 & 9 & $13.5 \pm 7.7$ \\
\hline 大動脈ピーク流量 & $(l / \mathrm{min})$ & 14.5 & 16 & 21 & 17.5 & 17.5 & $17.3 \pm 2.4$ & 15.5 & 19 & 23.1 & 18 & $18.9 \pm 3.2$ \\
\hline 大動脈最大流速 & $(\mathrm{cm} / \mathrm{s})$ & 34 & 33.2 & 43.5 & 41.3 & 55.0 & $41.4 \pm 8.8$ & 28.5 & 44.8 & 72.6 & 37.3 & $45.8 \pm 19.1$ \\
\hline 王力損失係数 & & 43.3 & 46.1 & 6.7 & 22.3 & 16.8 & $27.1 \pm 17.1$ & 62.6 & 6.3 & 9.65 & 16.4 & $23.7 \pm 26.2$ \\
\hline 断面積比狭窄度 & $(\%)$ & 79 & 80 & 58 & 74 & 70 & $72.2 \pm 8.9$ & 82 & 58 & 64 & 68 & $68 \pm 10.2$ \\
\hline
\end{tabular}

表 2 各症例の大動脈径, 左室大動脈間圧差, 大動脈ピーク流量, 大動脈最大流速, 圧力損失係数, 断面積比狭窄度 


\section{結語}

大動脈弁位 SJM 弁 $21 \mathrm{~mm}$ 縫着群の断面積比狭窄度 は平均 $72 \%, 23 \mathrm{~mm}$ 縫着群のそれは $68 \%$ であった，従 来の報告で $75 \%$ 以下であれば臨界狭窄以下であるとい われて扮り，通常の心拍出量下ではこの SJM 弁によっ
て生じる圧力損失は左室の後負荷として許容できると考 えられる。しかし $75 \%$ 以上の症例もあるので注意深い 経過観察が必要であり, 現在臨木経過を検討中である.

文 献 1) 白倉昌明ほか：管路，機械設計便覧，機械設計便 覽編集委員会編, pp.1936-1964, 丸善, 東京, 1973.

\title{
128 先天性心疾患に対する $\mathrm{SJM}$ 弁移植 13 例の経験
}

\author{
兵庫県立尼崎病院心臟センター 外科 \\ 節 家直已岡本文雄三宅俊治清田芳春 \\ 藤 原 慶一菅原英 次横田祥夫
}

最近 5 年間にわれわれは 13 例の先天性心疾患に対し, SJM 弁を用いた根治手術を経験したので，その手術成 績和よび遠隔期の弁機能に関して報告する.

\section{対象および方法}

手術の対象となった13症例を移植した弁位別に表 1 に

表 1 先天性心疾患に対する SJM 弁移植術症例 肺動脈弁位

\begin{tabular}{|c|c|c|c|c|}
\hline 症 例 & $\begin{array}{c}\text { 年 }{ }^{\text {齢 }} \\
\text { (体重, } \mathrm{kg} \text { ） }\end{array}$ & 手術診断 & サイズ & 転㛿 \\
\hline 1. & 5 歳 (18) & $\begin{array}{l}\text { PPA } \\
\text { Post Brock \& B-T }\end{array}$ & $21 \mathrm{~A}$ & 生 \\
\hline 2. & 3 歳 (11) & Absent PA valve & $21 \mathrm{~A}$ & 生 \\
\hline 3. & 6 月 (5) & Absent PA valve & $19 \mathrm{~A}$ & 生 \\
\hline 4. & 3 月 (4) & Absent PA valve & $19 \mathrm{~A}$ & 死 \\
\hline 5. & 5 歳 (16) & $\mathrm{TF}$ & $19 \mathrm{~A}$ & 生 \\
\hline 6. & 16歳 (50) & Pseudotruncus & $21 \mathrm{~A}$ & 死 \\
\hline 7. & 10歳 (37) & TF (reop.) & $23 \mathrm{~A}$ & 生 \\
\hline 8. & 12歳 (21) & Pseudotruncus (reop.) & $23 \mathrm{~A}$ & 生 \\
\hline 9. & 10歳 (23) & $\begin{array}{l}\text { TF, Absent PA valve } \\
\text { (reop.) }\end{array}$ & $23 \mathrm{~A}$ & 生 \\
\hline
\end{tabular}

僧帽弁位

\begin{tabular}{lllll}
\hline 10. & 4 歳 (16) & TGA (III) & $25 \mathrm{M}$ & 死 \\
11. & 7 Post Rastelli op. & $27 \mathrm{M}$ & 死 \\
\hline
\end{tabular}

大動脈弁位

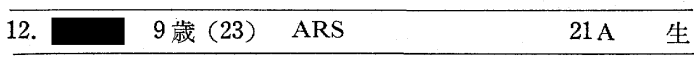

三尖弁位

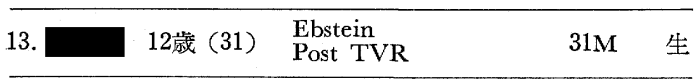

示す. 肺動脈弁位に移植術を施行し生存した 7 例中 6 例 に術後心カテーテル検查を行った. また外来にて経過観 察中, 心断層ェコーにて右室機能㧍よび移植弁機能の評 価を行った。

\section{成 績}

13 例中 4 例が病院死した. 表 1 の症例 4 法術後 6 力月 目に呼吸不全で, 症例 6 は術後 13 日目敗血症にて失っ た.また症例 10 および 11 は準緊急的に MVRを施行 した症例である。

肺動脈弁位に移植した症例で生存した 7 例のうち 5 例 の術後心カテーテル検査成績掞よび心断層エコー法より みた右室収縮期圧の大動脈収縮期圧に対する比 $\left(R V / A_{0}\right.$ 比) ${ }^{12}$ を表 2 に示す. 症例 2 は術後外来にて follow-up 中, SJM 弁の閉鎖音が聴取できなくなった absent PA valve の 1 例で術後 1 カ月目の心カテーテル検査では $R V / A_{0}$ 比 0.31 であったものが術後 39 カ月目には 0.55

表 2 肺動脈弁位移植症例の術後心断層 echo による $R V / A_{\text {。 推定值 }}$

\begin{tabular}{|c|c|c|c|}
\hline \multirow{2}{*}{ 症 例 } & \multirow{2}{*}{$\begin{array}{c}\text { 年 齢 } \\
\text { (体重, } \mathrm{kg} \text { ) }\end{array}$} & \multicolumn{2}{|l|}{$R V / A_{0}$ 比 } \\
\hline & & $\begin{array}{c}\text { Echo } \\
\text { (術後月数) }\end{array}$ & $\begin{array}{l}\text { 心出 } \\
\text { (術後月数) }\end{array}$ \\
\hline 1. & 5 歳 (18) & $\begin{array}{l}0.5 \text { 以下 }(29) \\
0.5 \text { 以下 }(43)\end{array}$ & $0.29(1)$ \\
\hline 2. & 3 歳 (11) & $\stackrel{0.5}{\text { SJM 弁の可動性なし? }}$ & $\begin{array}{l}0.31(1) \\
0.55(39)\end{array}$ \\
\hline 3. & 6 月 $(5)$ & $\begin{array}{l}0.5 \\
\mathrm{SJM}\end{array}$ 弁の可動性なし? & $0.39(1)$ \\
\hline 5. & 5 歳 (16) & (33) & $0.60(1)$ \\
\hline 9. & 10歳 (23) & $\begin{array}{l}0.5 \\
0.6\end{array}$ & $0.42(1)$ \\
\hline
\end{tabular}

